\title{
Agro Bussines Development Nexus Tourism In West Sumatera Province
}

\author{
${ }^{1}$ ANSOFINO, ${ }^{2}$ ZUSMELIA \\ ${ }_{12}$ STKIP PGRI Sumatera Barat, Jl. Gunung Pangilun No.1, Padang, West Sumatera, Indonesia \\ email: ${ }^{1}$ ansofino@stkip-pgri-sumbar.ac.id ; ${ }^{2}$ zusmelia@stkip-pgri-sumbar.ac.id
}

\begin{abstract}
The focus of this research is to analyze the future and backward linkages of agro-industry products that support the West Sumatra tourism creative industry and vertical integration between typical snack food products of West Sumatra culinary that have added value. This study uses a regional economic approach with the Grubel-Llyod index method and analysis of input output from snack industry sector. Result of the study shows that the market potential of West Sumatra agro-industry products still has low added value due to the low value of intermediate inputs compared to the final demand. Increasing the added value of agro-industry products based on food crop products is carried out by external regions such as North Sumatra and Riau. Integration between vertical market and regional external markets occurs in fruit-based agro industry products such as mangosteen, jackfruit, and bananas, which are shown by the highest Grubel-Llyord Index value with the demand value is lower than the final demand. The development of agro-industry food products and agro-business activities supporting culinary tourism in West Sumatra can be conducted by increasing the added value of superior products through agro-processing at household producer level and creating agglomeration to enhance local demand.
\end{abstract}

Keyword: Agro-industry, value-added, vertical market

\section{Introduction}

Agro-industry is the ability to create products portfolio from raw agricultural products converted into high value final or semi-final products (Sharma et al., 2004). The steps taken to make products portfolio from raw agricultural products are (Jonkman, et al 2015: 1291) firstly, developing portfolio agricultural products based on composition and function of raw products. Secondly, exploring synthesis process to create superstructure of new agricultural portfolio products. Thirdly, using a multi-purpose optimization method to develop better design of agricultural portfolio products. Therefore, it needs to consider the appropriate structure, function, time and space. According to Bongers et al. (2009), product-driven process synthesis (PDPS) has nine levels: framing level, consumer wants, product attributes, input-output level, task network, mechanism and operational window, multi-product integration, equipment, selection and design, and multiproduct-equipment integration, (Bongers \& Almeida-Rivera, 2009:233-234).

One of the examples is cassava agricultural products. The early stage after harvesting is a stripping process and stabilization in order to extend the shelf life and proceed to the process of selection, for details see figure 1 . At this stage, raw cassava can be sorted out for exporting products portfolio and local needs. The next steps are washing and cutting stage to produce fresh cassava product portfolio. Then, the drying process is carried out to make dried cassava product portfolio. The product portfolio can be sold at other times if fresh cassava supply is abundant and causing low price. It means the drying process gives benefits to overcome the time constraints in selling this agricultural product. It says "prices are going down during the harvest" so that these derivative products can be sold in higher price cycles during the harvest. Agricultural goods are used as industrial raw materials. Agro-based

Received: 2018-10-02, Revision: 2019-03-05, Accepted: 2019-05-28

Print ISSN: 0215-8175; Online ISSN: 2303-2499. DOI: http://dx.doi.org/10.29313/mimbar.v35i1.4111

Accredited $\mathbf{S 2}$ based on the decree No.10/E/KPT/2019 until 2024. Indexed by DOAJ, Sinta, Garuda, Crossreff, Dimensions 


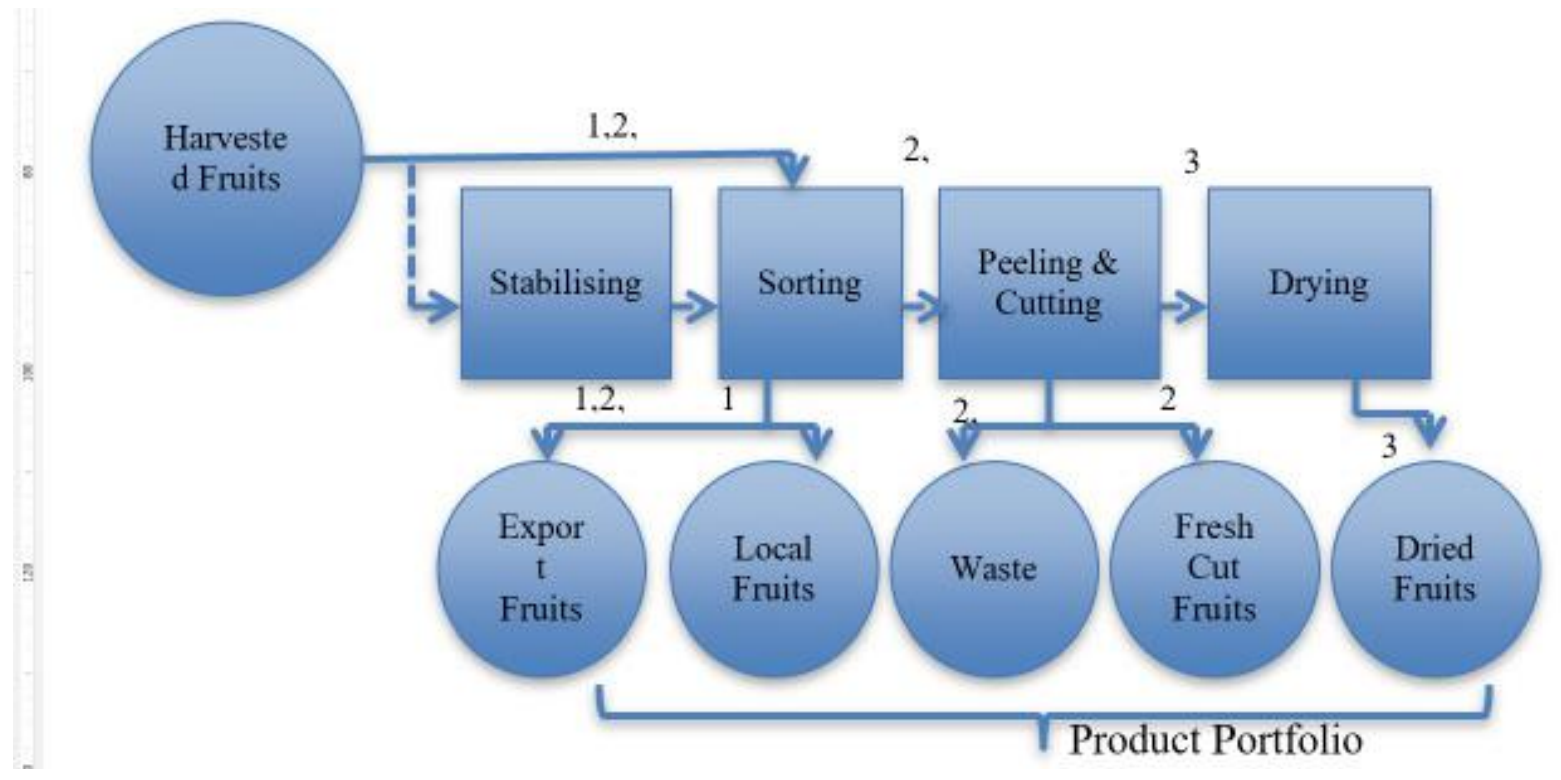

Source: Jonkman, Bloemhof, Vorst, \& Padt, (2015:1292)agro-materials are converted into a range of valuable semi-finished and finished products. To reach a sustainable, resource efficient food system, the optimal process pathways converting the agro-material into these products have to be identified. To identify these pathways, a systematic Process Synthesis (PS

Figure 1. Processing of agro-industry derivative product to increase added value

industries are quite important in most of the less developed countries. (Marjit, 1991), (Wen, 2004).

Changes of value in agro-industry agricultural products are: first, from a low added value of agricultural products into a high ones: second, from an agricultural output to a manufacture and service; third from an intensive labor to an intensive capital, expertise, and technology; four, from an import substitution sector to a nontraditional export sector; five, from a food and textile processing to a chemical industry, metal product, electronic and mechanical equipment (Bhattacharyya, 2002) (Zhu \& $\mathrm{Fu}, 2013)$. Activating the sub-sector agroindustry needs the availability of resources for investment, skilled-labor, new technology for product development to put high added value, compatibility of capital and labor to overcome the economics obstacles of , even the availability of technology transfer from outside parties as a form of foreign assistance for the development of agro-industry in developing countries which would be carried out later on by skilled-workers (Kaneda, 2003:91-93), (Balasa Bela, 2011). Therefore, this agro-based industry is an important basis to add value to marketed agricultural products and increase farmers' income(Greenaway et al., 2015). Intensively, the changes are made from commodity to processing high value-added products that focus on product development based on innovation in the sustainability of agricultural products, quality and safety, to providing services throughout the supply chain. Those should be developed in starting the enhancement of agro-industry in a region. (Wang $\&$ Xie, 2004),

The main industries agreed upon by the provincial, district, and regional government to develop the economy of West Sumatra are: (1) Snack industry based on raw materials such as cassava, sweet potato, shallot, beef cattle, rice flour, and glutinous rice; (2) Cocoa Industry; (3). Gambir-processing Industry, (4) Coconut-processing Industry; (5) Fishery and marine product processing-industry; (6) Essential oil Industry; (7) Alsintan Industry; (8) Non-timber forest products industry.

There are several groups of agricultural crops and horticultural products being used in the snack industries. First, cassava-based snack industry which uses raw cassava as its basic material and processes them into snacks called Sanjai crackers and Kaliang crackers that are very well-known in West Sumatra, and also sweet potato crackers., cassava can also be made into sweet potato flour or tapioca flour as an ingredient to make various types of other snacks. In addition to 
cassava, there are also potatoes that often used as raw materials for making snacks such as potato crackers and potato chips. Other plant in this group is onion which mostly used as one of the important ingredients in making the food. Second, nut-based snack industry which uses peanut-based ingredients to make snacks such as kipang kacang, rakik kacang, and peanut butter.

There is also soy bean-based snack industry which makes tofu, tempe, and tempe chips. Third, banana-based snack industry with products of Pisang Salai (driedbanana), banana chips, banana pancake, and many others. Four, corn-based snack industry which makes roasted corn, boiled corn, and juiced corn. Five fruit-based snack industries with fruits of jackfruit, rambutan, durian, and mangosteen processed into chips or juices. Six, grain-based snack industry, especially rice and glutinous rice, which can be processed into food ofGelamai, Beras Rendang, and other types of snacks made from rice flour and sticky rice.

Research questions to focus the discussion are: first, how is the market potential of agro-industrial products based on agricultural products? Will the creation of added value be captured and used by business actors in West Sumatera?. Second, how is the relation between input and output of agricultural products with the external market in West Sumatra? Does market integration occur vertically between internal regions? Third, how can the potential and opportunities of raw materials based on agro-industry for food crops development be able to support culinary products and the development of tourism in West Sumatra?

\section{Research Methodology}

This study applied a regional economic approach with a method of value-added analysis and calculated the forward and backward linkages of superior products that become the basis of West Sumatra culinary tourism so far. it also used calculating index method of Grubel-Llyord (intra industry trade index) and production growth and tracing industrial trees for superior snack products from horticultural, fisheries, and forestry food sub-sector in West Sumatra Province. Types of data used were secondary data collected from the West Sumatra Provincial Bureau of Statistics (BPS), input-output data, and superior product profile data of food, horticultural, fishery and forestry subsectors of West Sumatra Province. Primary data were collected by interviewing snack industry entrepreneurs through a focus group discussion in order to support the development of culinary industry and tourism activities in West Sumatra Province.

The calculation for intra industry trade specialization among industry provinces in Sumatra used the following formula of calculation:

Grubel - Llyod Index $=$
$I I T=\frac{1}{n} \sum \frac{\left|x_{i}-m_{i}\right|}{x_{i}+m_{i}}$

Where: and refer to export and import of food and beverage industry and $n$ is the numbers of commodity categories considered, if the index value approaches one, there is a high intensity of trade, and vice versa.

The calculated value-added analysis and the forward and backward linkages of superior product used input-output (I-O) data of West Sumatra, 2016. Each input of coefficient is calculated with a method:

$a_{i j}=\frac{x_{i j}}{x_{j}}(i, j=1 \ldots \ldots n)$

equation (2)

$v_{h j}=\frac{v_{h j}}{x_{j}}(j=1 \ldots . n)$

$\alpha_{j}=\frac{\sum_{i=1}^{n} b_{i j}}{\frac{1}{n} \sum_{i} \sum_{j} b_{i j}}$

equation (4)

$\beta_{j}=\frac{\sum_{j=1}^{n} b_{i j}}{\frac{1}{n} \sum_{i} \sum_{j} b_{i j}}$

equation (5)

Where: $a_{i j}=$ coefficient input between sector-i and sector output, $j$. $v_{h j}=$ coefficient of value added sector $\mathrm{j}$ component $h$, to output sector $j$.

$\alpha_{j}=$ index of distribution ability (forward linkages)

$\beta_{j}=$ degree of sensitivity (backward linkages).

The rules of thumb for distribution ability index are if the index values is large than one, then there is a linkage of this sector going forward. In addition, if sensitivity index is greater than one, this sector experiences backward linkage. (Bappeda dan BPS Sumbar, 2017:50-54), also see (Anas, Tamin, \& Wibowo, 2015)the increase of the output in the production sectors is expected to develop the regional economy. Compared to other Asian countries, logistics cost in Indonesia is much higher than that of other nations in the region. Reaching up to $25 \%$ of the Gross 
Domestic Product (GDP.

\section{Results And Discussion}

\section{Level of Competitiveness of Western Sumatra Snack Industry to Support Culinary Services for Tourists}

West Sumatra Province has an advantage in the snack industry in terms of raw materials for food and plantation subsectors, as indicated by the Grubel-Lyord index value which is higher than other types of snack industries. Among the provinces in Sumatra, some with the highest value of Grubel-Lyord index for the snack industry are South Sumatra, Lampung, North Sumatra, and the Riau Islands.

Based on figure 2, the value of trade in snack industry of West Sumatra is still far below other provinces of North Sumatra, Riau, and Riau Islands which are tourists gateways to go to West Sumatra. This is in line with the results of vertical integration analysis of agroindustry derivative products markets made from food crops which are the mainstay of West Sumatra culinary industry products for tourist consumption, as it is shown in figure 3.
West Sumatra's agroindustry- and agricultural horticulture market potentials and opportunities have seven types of raw materials: corn, potatoes, cassava, peanuts, soybeans, shallots, jackfruit, and mangosteen. These raw material produce various derivative products for snack industry. Among them, derivative products made from raw jackfruit, mangosteen, shallots, and soybeans have the highest input value. It indicates that agroindustry products such as jackfruit chips and mangosteen supplement drinks have a large imported component.

The value of imported components from intermediate inputs to produce derivative products also provides information that vertical market integrates with markets outside the region and global markets if these inputs come from abroad.

Figure 3 shows that snacks made from jackfruit, mangosteen, shallot, and soybeans are commodities with very high input values, so that they have a vertical market link with outside markets. It means the added value of agroindustry derivative product has been captured by external regions, while West Sumatra agroindustry shows its weakness for

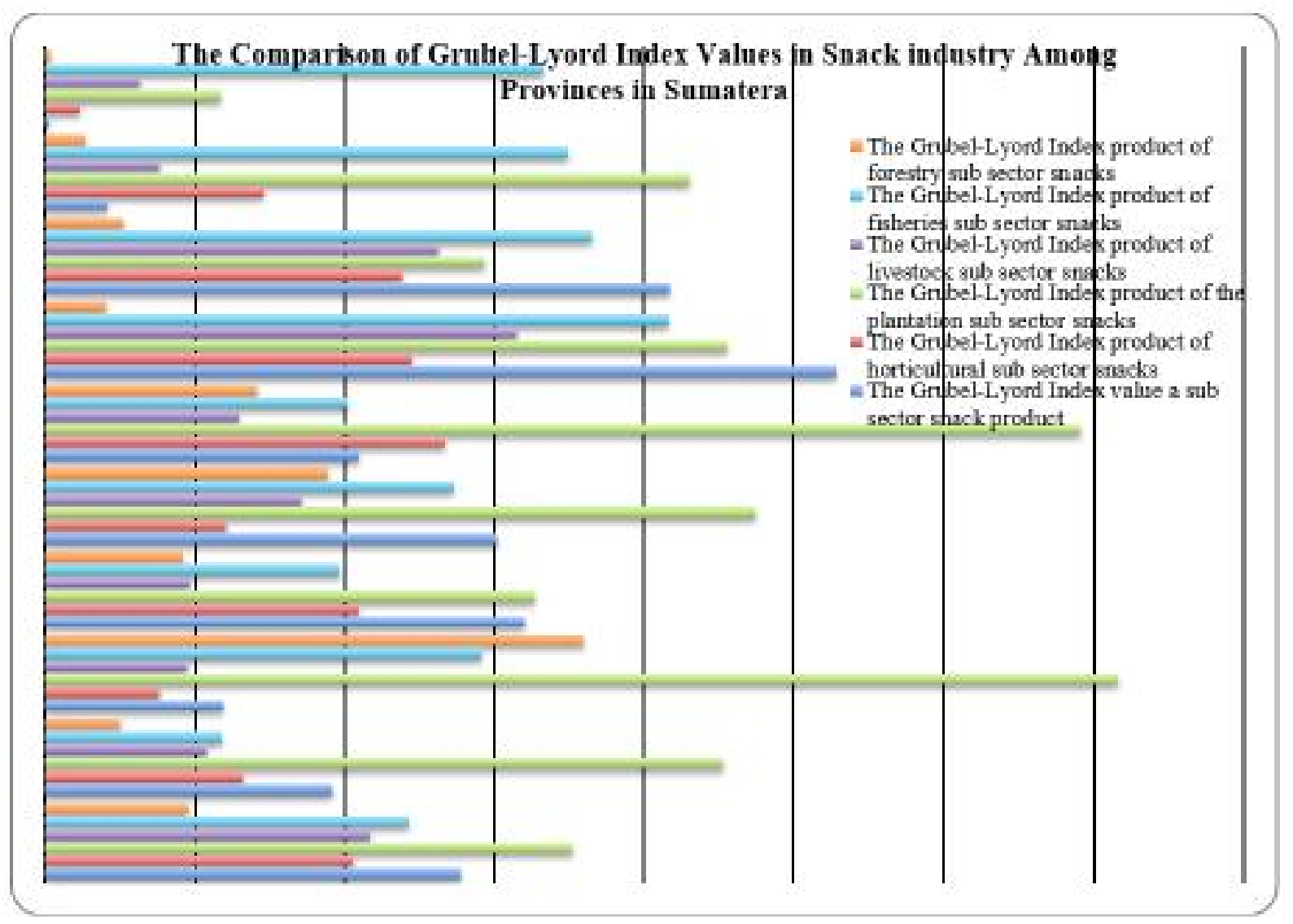

Figure 2. The Intra Industry Trade Value in Snack Industry among Provinces in Sumatra 


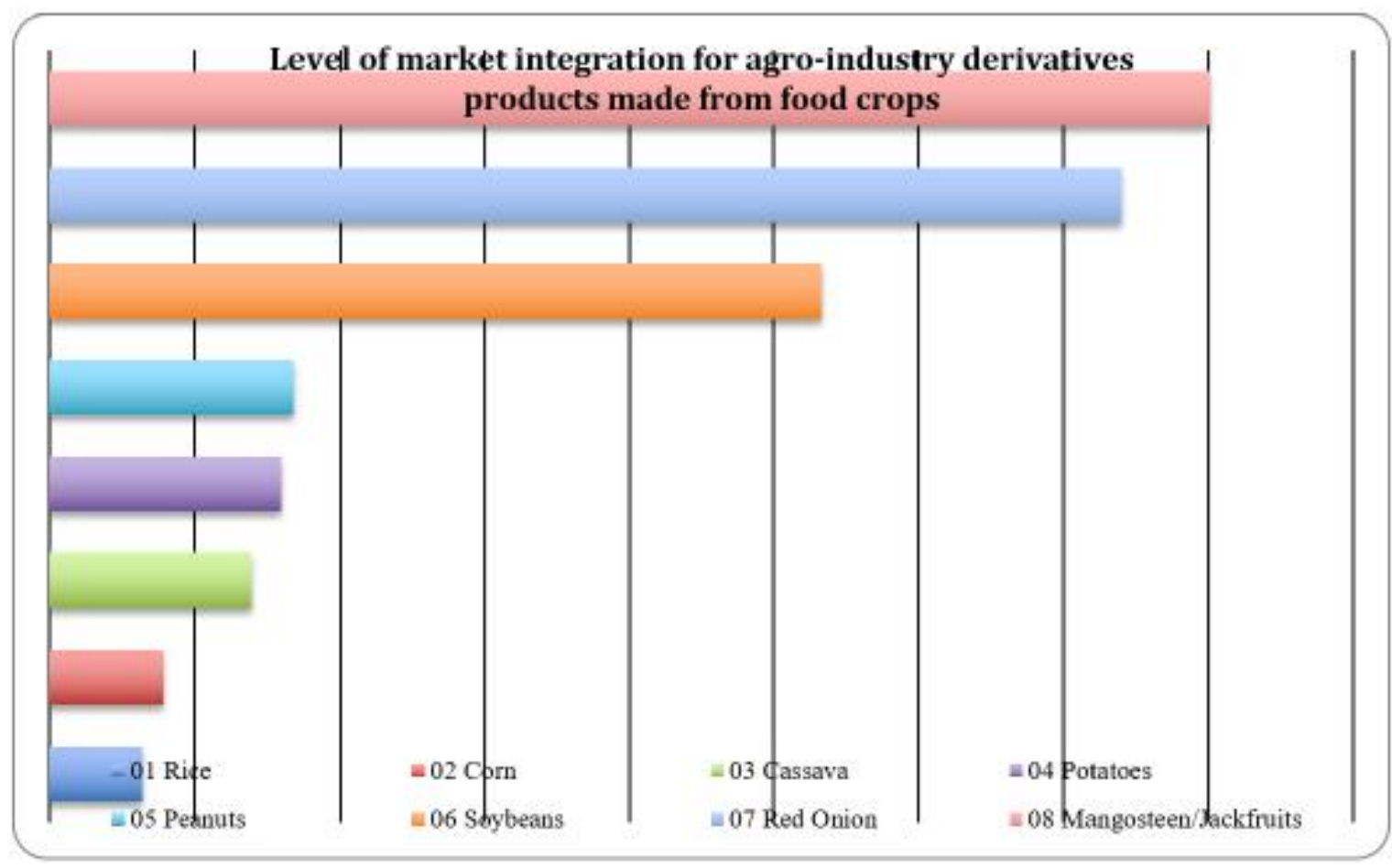

Figure 3. Comparison Chart of value added inputs between agro-industry derivative products made from food crops in West Sumatra

has not yet created agglomeration among the snack industries.

Transactions between input and output sectors among raw materials for snack industry have not been carried out by the region itself, but by outside provinces such as North Sumatra and Riau, especially for additional raw materials and packaging. Therefore, to develop West Sumatra snack food industry that supports services for tourists in culinary sector, the development of upstream downstream raw materials needs to be done.

\section{Potential and Opportunities of West Sumatra Snack Agro business and agro industry development}

West Sumatra's province agro-industry products are classified into four groups: (1) Superior products made from food crops and horticultural products consisting of tuberbased snack industry, nut-based snack industry, banana-based snack industry, corn-based snack industry, fruit-based snack industry, and grain-based snack industry; (2) Superior products made from plantation commodities consisting of cocoa processing industry, coconut processing industry, coffee processing industry, sugarcane processing industry, tea-processing industry, gambier- processing industry, and essential oilprocessing industry; (3) Superior products made from livestock products consisting of meat and dairy processing industries; (4) Superior products made from fish.

The main obstacles in developing West Sumatra snack agro-industry are the input sub-system, production sub system, off-farm sub-system, market sub system, and agribusiness supporting sub system, (Ansofino, 2014). Results of qualitative analysis show that processing obstacles at off-farm level become a leverage factor for the growth and movement of various sub-systems supporting the agro-industry and agribusiness systems and reinforcing the snack industry of culinary tourism mainstay in West Sumatra.

The main weakness at the level of off farm is the inability of raw materials supply to meet the increasing demand fluctuations with the low level of agro-processing activities at the household level. Agro-processing activities are generally carried out by entrepreneur with low added value and linkages among sectors. Diversification of processed-snack products in the third stage of industrial trees is still low. Agro-processing activities of sorting, washing, cutting, preserving, drying, and canning have not been done well yet. The demand for final products at the first level in industrial trees is still greater than the demand of processing 
Table 1

Potency of Tubers-Based Snack Industry

\begin{tabular}{lccccccc}
\hline No & $\begin{array}{c}\text { Raw } \\
\text { Material }\end{array}$ & $\begin{array}{c}\text { Planting } \\
\text { Area } \\
\text { (ha) }\end{array}$ & $\begin{array}{c}\text { Production } \\
\text { (Ton) }\end{array}$ & $\begin{array}{c}\text { Production } \\
\text { Growth } \\
2010- \\
2015\end{array}$ & $\begin{array}{c}\text { Gross } \\
\text { Added Value } \\
(209)\end{array}$ & $\begin{array}{c}\text { Forward } \\
\text { Linkage } \\
\text { (Distribution } \\
\text { Ability })\end{array}$ & $\begin{array}{c}\text { Derivative } \\
\text { Products }\end{array}$ \\
\hline $1 . \quad$ Cassava & 5318 & 208386 & 3,69 & 162197.65 & 0,6047 & $\begin{array}{l}\text { Sanjai } \\
\text { crackers, } \\
\text { karak kaliang }\end{array}$ \\
2 Potato & 3093 & 60048 & 87.95 & 31521.92 & 0.4998 & Potato Chips \\
and Meatball \\
3
\end{tabular}

Table 2

Potency of Nut-Based Snack Industry

\begin{tabular}{|c|c|c|c|c|c|c|c|}
\hline No & $\begin{array}{c}\text { Raw } \\
\text { Material }\end{array}$ & $\begin{array}{c}\text { Planting } \\
\text { Area } \\
\text { (ha) }\end{array}$ & $\begin{array}{l}\text { Production } \\
\quad \text { (Ton) }\end{array}$ & $\begin{array}{l}\text { Production } \\
\text { Growth } \\
2010- \\
2015\end{array}$ & $\begin{array}{l}\text { gross Added } \\
\text { Value (209) }\end{array}$ & $\begin{array}{l}\text { Forward } \\
\text { Linkage } \\
\text { (distribution } \\
\text { ability) }\end{array}$ & $\begin{array}{l}\text { Derivative } \\
\text { Product }\end{array}$ \\
\hline 1. & Peanut & 4087 & 5964 & $-34,91$ & 92985.53 & 0.5015 & $\begin{array}{l}\text { Rakik } \\
\text { peanuts, } \\
\text { Kipang } \\
\text { peanuts, }\end{array}$ \\
\hline 2 & Soybean & 296 & 353 & $-80,75$ & 18973.31 & 1.1014 & $\begin{array}{l}\text { Tofu, tempe. } \\
\text { Tempe Chips }\end{array}$ \\
\hline
\end{tabular}

Source: Result Analysis, 2017

results, especially in plantation-based agroindustry products.

Table 1 provides information about gross added values as the ratio between intermediate input and output, while forward linkages as the ability to spread the input power forward to produce its derivative products by using formula 3 and 4 . Input of cassava as raw material for food industry in West Sumatra has a smaller forward linkage value than 1 . It means the driving force of food industry such as flour industry and pastry industry are still low reflected in the demand value around 31.8 billion IDR. It is indeed still low compared to the value of final demand for 164.5 billion IDR. Therefore, the diversification of processed food products from raw cassava should still be improved.

The economics potency of snack industry using potato raw material is relatively smaller than cassava raw material. It was only
3,093 ha with production value of 60.1 billion IDR and the growth of $87.95 \%$ in 2010 and 2015, while the gross added value reaching 31.5 billion IDR. This potato raw material also does not have strong future linkages since its future linkage matrix value is smaller than 1 . It is shown by the low demand of 26.1 billion IDR compared to the value of final demand of 118.1 billion IDR. It can be simplified that the fundamental problem in the development of West Sumatra food industry, which is based on food crops, is the undeveloped agro-processing. Among the raw materials for the main snack processing industry in West Sumatra, the biggest linkages are fried onions and cassava.

Table 2 shows the potency of raw material for nut-based snack industry consisting of peanut and soybean. This soybean raw material is able to encourage the improvement of processing industry development in the future, which can be 
MIMBAR, Vol. 35 No. $1^{\text {st }}$ (2019)

Table 3

The Potency of Corn and Banana-Based Snack Industry

\begin{tabular}{|c|c|c|c|c|c|c|c|}
\hline No & $\begin{array}{l}\text { Raw } \\
\text { Material }\end{array}$ & $\begin{array}{l}\text { Planting } \\
\text { Area (ha) }\end{array}$ & $\begin{array}{l}\text { Production } \\
\text { (Ton) }\end{array}$ & $\begin{array}{l}\text { Production } \\
\text { Growth } \\
2010- \\
2015\end{array}$ & $\begin{array}{l}\text { Gross } \\
\text { Added } \\
\text { Value (209) }\end{array}$ & $\begin{array}{l}\text { Forward } \\
\text { Linkage } \\
\text { (distribution } \\
\text { Ability ) }\end{array}$ & $\begin{array}{l}\text { Derivative } \\
\text { Product }\end{array}$ \\
\hline 1. & Banana & 179326 & 141327 & 40.59 & 1343317 & 0.07236 & $\begin{array}{l}\text { Pisang salai, } \\
\text { Banana } \\
\text { Chips }\end{array}$ \\
\hline 2 & Corn & 87825 & 602549 & 70,09 & 2.527 & 2.8239 & $\begin{array}{l}\text { Processed- } \\
\text { Corn } \\
\text { Products }\end{array}$ \\
\hline
\end{tabular}

Sources: Result Analysis, 2017

Table 4

The Potency of Jackfruit and Mangosteen Industry Materials for The Next Product

\begin{tabular}{|c|c|c|c|c|c|c|c|}
\hline No & $\begin{array}{c}\text { Raw } \\
\text { Material }\end{array}$ & $\begin{array}{l}\text { Planting } \\
\text { Area } \\
\text { (ha) }\end{array}$ & $\begin{array}{l}\text { Production } \\
\text { (Ton) }\end{array}$ & $\begin{array}{l}\text { Production } \\
\text { growth } \\
2010- \\
2015\end{array}$ & $\begin{array}{c}\text { gross } \\
\text { Added } \\
\text { Value (209) }\end{array}$ & $\begin{array}{c}\text { Forward } \\
\text { Linkage/ } \\
\text { Distrubution } \\
\text { Ability }\end{array}$ & $\begin{array}{c}\text { Derivative } \\
\text { Product }\end{array}$ \\
\hline 1. & Jackfruit & 63932 & 7458 & 4,38 & 1343316.7 & 0.3618 & $\begin{array}{l}\text { Jackfruit } \\
\text { Chips and } \\
\text { Juice }\end{array}$ \\
\hline 2 & Mangosteen & 166396 & 29378 & 617.94 & & & $\begin{array}{l}\text { Mangosteen } \\
\text { juice, } \\
\text { Leaves, } \\
\text { Drink and } \\
\text { Supplement }\end{array}$ \\
\hline
\end{tabular}

Sources: Result Analysis, 2017

seen from the coefficient value of distribution ability bigger than 1 . However, the growth of peanut and soybean production is drastically declining by more than fifty percent in 2015. Gross added value reflecting the linkages of each sector is also still small because there are only four sectors related to this raw material of peanuts and soybeans, namely chicken and duck farming sector, snack industry, hotel and restaurants, and social services community.

The low future linkages of peanut raw material are also proven by the value of present demand which reflects the much smaller relationship in each sector, i.e. 29.7 billion IDR for peanuts and 10.4 billion IDR for soybean compared to the value of final demand of 95.2 million IDR and 21.6 billion IDR for peanuts and soybean respectively. Based on that, it can be stated that the potency of nut-based snack industry is still low in its added value and each-sector linkages.
Therefore, to develop the nut-based food industry, it is necessary to raise the added value through increasing surplus business by improving the diversification of industry trees. Thus, by comparing high final demand to intermediate demand, it can be seen that peanut and soybean products have larger directly-consumed, compared to the level of consumption of derivative products, such as kipang kacang and rakik kacang.

Regarding the relatively small planting and production area, it can be said that the increase of peanut and soybean will be strongly driven by the present demand and final demand. Therefore, in the development of agro-industry, it is necessary to improve the processing of peanut and soybean products to develop derivative products.

Table 3 illustrates the potency of banana-based snack industry which has a low future linkage seen from the coefficient 


\section{Table 5}

The Potency and Opportunity of Livestock Sub Sector-Based Agro-Industry

\begin{tabular}{|c|c|c|c|c|c|c|c|}
\hline No & $\begin{array}{c}\text { Raw } \\
\text { Material }\end{array}$ & Population & Production & $\begin{array}{l}\text { Production } \\
\text { Growth } \\
2010- \\
2015\end{array}$ & $\begin{array}{l}\text { gross Added } \\
\text { Value (209) }\end{array}$ & $\begin{array}{c}\text { Forward } \\
\text { linkage/ } \\
\text { Distribution } \\
\text { Ability }\end{array}$ & $\begin{array}{l}\text { Derivative } \\
\text { Products }\end{array}$ \\
\hline 1. & Beef Cattle & 397548 & 26007 & 26,18 & 609133.27 & 3.7082 & $\begin{array}{l}\text { Rendang, Slice- } \\
\text { Dried Meat, } \\
\text { Milk, Cracker }\end{array}$ \\
\hline 2. & $\begin{array}{l}\text { Buffalo } \\
\text { Cattle }\end{array}$ & 121939 & 2678381 & 2,68 & 609133.27 & & $\begin{array}{l}\text { Rendang, Slice- } \\
\text { Dried Meat, } \\
\text { Milk, Cracker, } \\
\text { dadiah/yogurt }\end{array}$ \\
\hline 3. & $\begin{array}{l}\text { Chickenand } \\
\text { Duck } \\
\text { Cattle }\end{array}$ & 18445762 & 20063153 & 23,42 & 597716.78 & 0.6586 & $\begin{array}{l}\text { Chicken Meat, } \\
\text { Egg, Nugget }\end{array}$ \\
\hline
\end{tabular}

Source: Result, Analysis, 2017

Table 6

The Potency and Opportunity of Livestock Sub Sector-Based Agro-industry

\begin{tabular}{lccccccc}
\hline No & $\begin{array}{c}\text { Raw } \\
\text { Material }\end{array}$ & $\begin{array}{c}\text { Production } \\
\text { (Tons) }\end{array}$ & $\begin{array}{c}\text { Production } \\
\text { Growth } \\
2010-2015\end{array}$ & $\begin{array}{c}\text { Present Demand } \\
\text { (Transaction Value } \\
\text { among sectors) }\end{array}$ & $\begin{array}{c}\text { gross } \\
\text { Added } \\
\text { Value } \\
(209)\end{array}$ & $\begin{array}{c}\text { Forward } \\
\text { linkage and } \\
\text { Distribution } \\
\text { Ability) }\end{array}$ & $\begin{array}{c}\text { Derivative } \\
\text { Product }\end{array}$ \\
\hline $1 . \quad$ Rattan & 227207 & 180,76 & 20784.19 & 202931.55 & 0,3948 & $\begin{array}{c}\text { Rattan } \\
\text { Furniture }\end{array}$
\end{tabular}

Source: Result Analysis, 2017

value of distribution ability smaller than 1. Whereas, the coefficient value of corn raw material is larger than 1 , which means it has a bigger linkage in the future. Meanwhile, the positive production growth of banana raw material reached 40, 59\% in 2010 and 2015 and corn raw material achieved 70,09\%

Bananas as raw material for food industry such as pisang salai and banana chips are related to the food preservation industry and pastry snack industry. The amount of input of pisang salai industry and banana chips is 235.9 billion IDR. This value reflects the linkages between industry sector of pisang salai and banana chips processing. Meanwhile, the final number of demand is 1,267 billion IDR, which means it is greater than number of demand among those inter-sector transaction reflections. This means the raw material of bananas and corn have experienced development obstacles to diversification derivative products as raw material sectors such as food and beverages, hotels, and restaurants. The final demand is still greater than present demand, meaning that the raw material product has a higher selling point to be sold to the last customer.

The dominant raw materials for the development of fruit-based snack indu stry are jackfruit and mangosteen. Jackfruit planting area in 2015 was 63,932 trees and 166,396 of mangosteen trees. Jackfruit production in 2015 was 7458 tons and mangosteen was 29,378 tons.

Table 4 shows the gross added values as the ratio between intermediate input and output, while the forward linkages as the ability to spread input power forward to produce derivative products by using formula 3 and 4. Data description shows that the future linkages of raw material for jackfruit and mangosteen are still smaller than 1. Gross added value is quite larger, reaching 1,343 billion IDR. The largest one contributed by the 
business surplus for 1,223 billion IDR and the rests are supported by salary, indirect wages, and taxes.

The demand for jackfruit and mangosteen raw material reaches 235.9 billion IDR, which is still smaller than the final demand achieving 1,257 billion IDR. It means direct consumption of jackfruit and mangosteen raw So material is still greater than the use of input between other sectors requiring Jackfruit and mangosteen to produce derivative products. This is reinforced by the large number of present inputs showing the linkages between sectors in inter-sector transactions achieving 149.4 billion IDR. Therefore, it is necessary to increase jackfruit and mangosteen processing into derivative forms through agro-processing such as sorting, washing, cutting, picking, drying, and canning order to made overcome the time constraints of marketing.

The potency and opportunity of agroindustry development in plantation sub-sector in West Sumatra are cocoa, coffee, coconut, sugar cane, tea, gambir, and essential oils. The potency of agro-industry development for this plantation sub-sector used planting area data and the amount of production in the period of 2010 to 2015. In addition, the opportunity for developing agro-industry based on plantation sub-sector used an analysis of West Sumatra's input and output data. It is carried out especially to the amount of gross added value contain number of forward linkage matrix of raw material for main plantation sub-sector and the potential number of the present and final demand for the raw material production. Thus, it can explain the linkage structure of this raw material to its derivative product.

The biggest gross added value was achieved by cocoa raw material reaching 402.43 billion IDR, followed by coconut and coffee. Nevertheless, there are three plantation-based agro-industry raw materials that have the forward linkage greater than 1, namely coconut, sugar cane, and essential oils. It means these three raw materials are related to their stronger variety of derivative products that encourage an increase in the production demand. it is proved by the value of demand that reached more than half of the final demand value, even for the raw materials of palm oil and cane, with the value of demand achieved almost one percent of the final demand, so that this raw material has a strong forward linkage. It is implied good prospects in developing raw material plantation-based agro-industry in West Sumatra, which in line with the opinion of Bongers et al. (2009) stating the stage of developing high valueadded products is to integrate various input products to produce new products.

Table 5. illustrates gross added values as the ratio between intermediate input and output, while the forward linkages as the ability to spread input power forward to produce its derivative products by using formula 3 and 4 . The growth of livestock-based agro-industry of raw material production has been positive in 2010 and 2015. Gross added value to increase added value of beef and buffalo cattle reached 609.1 billion IDR consisting of $34.83 \%$ of wage and salary sources and $61.53 \%$ for business surplus. Meanwhile, the share for indirect taxes is still low, which is only $0.88 \%$. The gross added value for broilers reaching 597.7 billion IDR contributed by $41.47 \%$ of business surplus, $51.57 \%$ of business surplus, and indirect tax of $5.36 \%$.

The potency and opportunity of forestrybased agro-industry development in West Sumatra are agro-industry made from nontimber forest products such as rattan, bamboo, mushrooms, and honey (Zusmelia, 2012). The potency of agro-industry development for this forestry sub-sector used data of numbers of planting and production in the period of 2010 to 2015. In addition, the opportunity for developing forestry sub sector raw material agro-industry used input and output data analysis of West Sumatra, especially the amount of gross added value, the number of forward linkage matrix, and the potency of present demand and final demand of raw material production. Thus, it can explains the linkage structure of these raw materials to their derivative products.

Table 6 illustrates the gross added values as the ratio between intermediate input and output, while the forward linkages as the ability to spread input power forward to produce its derivative products by using formula 3 and 4 . The rattan raw material production growth is quite high from 2010 to 2015 where the value of the linkages among sectors reaching 20.8 billion IDR. It means $9.71 \%$ of the total final demand and shows low inter-sector transactions. The value of the forward linkage coefficient is smaller than 1 , which means this raw material has not been able to provide a strong support for the development of rattan-based agroindustry in the future. In other words, the 
Table 7

The Potency and Opportunity of Fishery Sub Sector-Based AgroIndustry

\begin{tabular}{|c|c|c|c|c|c|c|c|}
\hline No & $\begin{array}{c}\text { Raw } \\
\text { Material }\end{array}$ & $\begin{array}{l}\text { Production } \\
\text { (Tons) }\end{array}$ & $\begin{array}{l}\text { Production } \\
\text { Growth } \\
2010- \\
2015\end{array}$ & $\begin{array}{c}\text { Present } \\
\text { Demand } \\
\text { (Transaction } \\
\text { Value } \\
\text { among } \\
\text { Sectors) } \\
(180) \\
\end{array}$ & $\begin{array}{l}\text { Gross Added } \\
\text { Value (209) }\end{array}$ & $\begin{array}{c}\text { forward } \\
\text { linkage/ } \\
\text { Distribution } \\
\text { Ability ) }\end{array}$ & $\begin{array}{l}\text { Derivative } \\
\text { Product }\end{array}$ \\
\hline 1. & $\begin{array}{l}\text { Sea } \\
\text { Water } \\
\text { Fish }\end{array}$ & 186774,50 & 12,28 & 225783.91 & 976123.7 & 1,0692 & $\begin{array}{l}\text { Sea Fish } \\
\text { Canning, Fish } \\
\text { Drying }\end{array}$ \\
\hline 2. & $\begin{array}{l}\text { Fresh } \\
\text { Water } \\
\text { Fish }\end{array}$ & $262.863,26$ & 1,40 & 131138.33 & 794267.26 & 0,6119 & $\begin{array}{l}\text { Smoked cat } \\
\text { Fish, Fresh } \\
\text { Water Fish } \\
\text { Processing }\end{array}$ \\
\hline
\end{tabular}

Source: Result Analysis, 2017

added value is still low. Nonetheless, rattan processing business into furniture is enough to provide benefits for labor absorption because the wage salary value reaches $34.59 \%$ of the gross added value received and the large portion of value added lies in the business surplus value reaching $60.34 \%$ of the total gross value added. It means the rattan agroindustry business is promising in profits for its entrepreneurs, even though its contribution to indirect tax is still small at only 2,388 million IDR or $1.18 \%$ of tax added value. Therefore, future development efforts should be more directed at increasing the final value through inside and outside demand of the region to raise the demands.

The potency and opportunity for developing fisheries-based agro-industry in West Sumatra is an agro-industry made from marine fish and freshwater fish. The potency of agro-industry development for fisheries sub-sector used data of a number of crops and the amount of production in the period of 2010 to 2015.

Table 7 shows gross added values as the ratio between intermediate input and output, while the forward linkages as the ability to spread input power forward to produce derivative products by using used formula 3 and 4 . The potency and opportunity for developing marine fisheries and inland fisheries-based agro-industry in the form of fish canning, fish drying, smoked-catfish and freshwater fish processing. The growth of marine and inland fisheries raw material products shows quite good growth reaching $12.28 \%$ and $1.40 \%$ respectively in 2010 and
2015.

This positive production growth is also strengthened by a large present demand of 225.8 billion IDR or $25.07 \%$ of the total final demand for marine fish production, while for inland fisheries is 13.1 billion IDR or $16.28 \%$ of the final demand. Therefore, it can be said that the linkages among sectors of raw materials for marine fisheries are quite extensive. However, the household/domestic demand consumption demand is greater than the value of exports to outside regions and abroad. If this demand can be increased, the present demand will also increase due to the rise of added value.

The forward linkage of marine fisheries with its derivative products in the form of processing and canning shows decent development potency due to its forward linkage value of 1.0691 , which is greater than 1. It means the opportunity of marine fishery products processing industry development has strong power to increase added value and diversification of derivative products. Since the coefficient value of inland fisheries forward linkage is still smaller than 1, an effort is needed to process the derivative products with higher added value. Nevertheless, the processing business of marine fish and inland fisheries has been able to provide a business surplus for $71.83 \%$ and $80.45 \%$ for gross added value. It is also able to create a startup business for workers because the value of wages and salaries of total value added reached $19.65 \%$ and $15.76 \%$. It means the prospect of exploring fishery derivative products, especially marine fisheries, is wide 
open and gives space to establish business opportunities and increasing community income.

\section{Conclusions}

The market potential of agro-industry products based on West Sumatra agricultural products still produces low added value because of the low value of intermediate inputs compared to the final demand. External regions such as North Sumatra and Riau province.managed to capture the opportunity to increase the added value of agro-industry products based on food crop products Raw materials sector of snack industry in West Sumatra have not yet been managed internally. Thus, Developing the culinary sector to support tourism services can be done by increasing the development of agricultural product processing industries especially in derivative products and their packaging.

Integration of vertical market with regional external markets occurs in fruit-based agroindustry products such as mangosteen, jackfruit and bananas, which are shown by the highest Grubel-Llyord Index value with the demand value is lower than the final demand. Therefore, it is necessary to increase the processing of jackfruit and mangosteen products into derivative forms through agroprocessing such as sorting, washing, cutting, preserving, drying, and canning to overcome the time constraints in its marketing.

The potential of agro-industry based on animal husbandries such as beef and buffalo with derivative products of rendang and dendeng is very high. It is shown by the high linkages in the future and large number of requests between internal regions compared to final demand, which means it has a strong impetus for developing the agro-industry based on beef and buffalo meat. The potential of agroindustry based on marine fisheries such as processing of marine fish products is greater because the future linkages are higher so that the opportunity for the marine fisheries processing industry development has the power to increase added value and diversification of derivative products. The low value of indirect taxes indicates that value added of these raw materials is still low along with a number of marine processing businesses.

The development of snack agro-industry and agro-business activities supporting culinary tourism in West Sumatra can be conducted by increasing the added value of superior products through agro-processing at the household producer level and, creating agglomeration to enhance local demand.

\section{References}

Anas, R., Tamin, O. Z., \& Wibowo, S. S. (2015). Applying input-output model to estimate the broader economic benefits of Cipularang Tollroad Investment to Bandung District. Procedia Engineering, 125, 489-497. http://doi.org/10.1016/j. proeng.2015.11.042

Ansofino. (2012). Grand Desain Industri Unggulan dalam rangka menuju Perubahan Struktur perekonomian Sumatera Barat. Menara I/mu, I. No: 27 (Januari).

Ansofino. (2014). Penentuan Lokasi Pasar Induk dan pasar satelit di Kabupaten Solok selatan. Universitas Islam Bandung (Unisba). Retrieved from https://ejournal. unisba.ac.id/index.php/mimbar/article/ view/460/763

Balasa Bela, B. (2011). Communications: Tariff reduction and trade in manufactures among the Industrial countries. American Economic Review, 56(3), 1. http://doi. org/10.1057/9780230226203.1976

Bappeda dan BPS Sumbar. (2017). Tabel I-O Provinsi Sumatera Barat. BPS Sumbar, 1. Retrieved from https://sumbar.bps.go.id/ linkTableDinamis/view/id/124

Bhattacharyya, R. (2002). Vertical and Horizontal Intra Industry Trade in Some Asian and Latin American Less Developed Countries. Journal of Economic Integration, 17(2), 273-296. http://doi.org/https:// doi.org/10.11130/jei.2002.17.2.273

Bongers, P. M. M., \& Almeida-Rivera, C. (2009). Product Driven Process Synthesis Methodology. Computer Aided Chemical Engineering (Vol. 26). Elsevier B.V. http:// doi.org/10.1016/S1570-7946(09)700392

Greenaway, D., Hine, R., Milner, C., The, S., Journal, E., Nov, N., ... Greenaway, D. (2015). Vertical and Horizontal Intra-Industry Trade: A cross Industry Analysis for the United Kingdom. The Economic Journal, 105(433), 1505-1518. Retrieved from http://www.jstor.org/ stable/2235113

Jonkman, J., Bloemhof, J. M., Vorst, J. G. A. J. van der, \& Padt, A. van der. (2015). A Sustainability Driven Methodology for Process Synthesis in Agro-Food Industry. Computer Aided Chemical Engineering (Vol. 37). Elsevier. http://doi.org/10.1016/ 
b978-0-444-63577-8.50060-7

Kaneda, M. (2003). Policy design in a dynamic model of infant industry protection. Journal of Development Economics, 72, 91-115. http://doi.org/10.1016/S03043878(03)00069-5

Marjit, S. (1991). Agro-based migration industry and rural-urban. Journal of Development Economics, 35, 393-398. http://doi.org/0304-3878/91/503.50 0 1991

Sharma, S. C., Wen, M., Rsdseth, A., Nordås, H. K., Kaneda, M., Huang, J., Jørgensen, J. G. (2004). Biotechnology boosts to crop productivity in China : trade and welfare implications. Journal of Development Economics, 75 (September), 27-54. http:// doi.org/10.1016/j.jdeveco.2003.07.005

Wang, P., \& Xie, D. (2004). Activation of a modern industry. Journal of Development Economics, 74, 393-410. http://doi. org/10.1016/j.jdeveco.2003.06.005

Wen, M. (2004). Relocation and agglomeration of Chinese industry. Journal of Development Economics, 73, 329-347. http://doi. org/10.1016/j.jdeveco.2003.04.001

Zhu, S., \& Fu, X. (2013). Drivers of Export Upgrading. World Development, 51, 221-233. http://doi.org/10.1016/j. worlddev.2013.05.017

Zusmelia, et al. (2012). Model pengembangan entreprenuership dalam pemberdayaan ekonomi rumahtangga di Minangkabau. Journal Mimbar, 26(June), 306-328. Retrieved from https://ejournal. unisba.ac.id/index.php/mimbar/article/ view/347/19 